\title{
Perch or plankton: top-down control of Daphnia by yellow perch (Perca flavescens) or Bythotrephes cederstroemi in an inland lake?
}

\author{
JOEL C. HOFFMAN, MEGHAN E. SMITH and JOHN T. LEHMAN \\ Department of Biology, Natural Sciences Building, University of Michigan, Ann Arbor, MI, U.S.A.
}

\begin{abstract}
SUMMARY
1. Seasonal termination of the vernal clear-water phase in Long Lake, Grand Traverse Co., Michigan coincided with severe size-selective predation on juvenile Daphnia pulicaria from 0.8 to $1.8 \mathrm{~mm}$ in length. This could be caused by predation by age- 0 yellow perch (Perca flavescens) or by the exotic predatory zooplankter Bythotrephes cederstroemi.

2. During the initial decline of Daphnia, Ivlev's electivity coefficient for yellow perch from 15.0 to $20.0 \mathrm{~mm}$ in length was 0.50 for copepods and -0.75 for D. pulicaria.

3. Bioenergetics modelling of both yellow perch and Bythotrephes demonstrates that, during the initial Daphnia decline, Bythotrephes consumed 1.5-5 times greater total mass than yellow perch. Furthermore, models in which Bythotrephes consumed juvenile Daphnia were more consistent with the timing of the Daphnia decline than those in which yellow perch consumed juvenile Daphnia.

4. The invasion of Bythotrephes into Long Lake seems to be a significant perturbation, introducing effects that propagate throughout the food chain. Bythotrephes created a possible bottleneck for age-0 yellow perch in late June by suppressing Daphnia.

Keywords: bioenergetics, Bythotrephes, Daphnia, perch, trophic cascades
\end{abstract}

\section{Introduction}

The seasonal clear water phase typical of many inland lakes has been attributed to intense grazing by herbivorous zooplankton (Lampert, 1978; Edmondson \& Litt, 1982; Lampert et al., 1986). An extended period of unusual water clarity has been associated with a trophic cascade (Hrbácek, 1962; Carpenter, Kitchell \& Hodgson, 1985; Carpenter et al., 1987; Brett \& Goldman, 1997), in which piscivores prey on planktivorous fish, thereby releasing grazers from predation and permitting a clear water phase. Subsequently, intense feeding by planktivorous fish reduces grazer numbers, truncating the clear water phase. A sudden decline in grazing zooplankton, especially Daphnia, has usually been attributed to predation by plankti-

Correspondence: John T. Lehman, Department of Biology, Natural Sciences Building, University of Michigan, Ann Arbor, MI 48109-1048, U.S.A. E-mail: jtlehman@umich.edu vorous fish such as minnows (Carpenter \& Kitchell, 1988) and yellow perch (Perca flavescens (Mitchill)) (Mills, Forney \& Wagner, 1987), but also to predation by Cyclops (Lampert, 1978) and a combination of starvation and fish predation (Lampert et al., 1986).

A clear water phase has been a regular feature in Long Lake, Grand Traverse County, Michigan (B. Lishawa, unpublished). At such times, Secchi disk transparency ranges from 10 to $19 \mathrm{~m}$. Daphnia pulicaria Forbes is dominant during the clear water phase, reaching a density exceeding $5800 \mathrm{~m}^{-3}$. Recent surveys of yellow perch in Long Lake indicate that most age classes are growing faster than the average for Michigan lakes (Michigan Department of Natural Resources, 1997). Perch data seem consistent with a trophic cascade interpretation, wherein D. pulicaria is the primary food, and the clear water phase ends when perch reduce the density of $D$. pulicaria. This could be similar to findings in Oneida Lake, New York, where control of Daphnia populations by age- 0 
yellow perch has been documented (Mills et al., 1987).

Long Lake hosts a second planktivore: B. cederstroemi Schoedler (Crustacea: Cladocera). Bythotrephes probably invaded Long Lake from nearby Lake Michigan, transported in bait buckets or boat wells. Bythotrephes is a voracious predator of mid-sized Daphnia (Lehman, 1988; Lehman, 1991; Lehman \& Cáceres, 1993; Yan \& Pawson, 1997). Bythotrephes may also compete for mid-size Daphnia with age-0 fish (Lehman, 1991).

The presence of two planktivorous predators, yellow perch and Bythotrephes, begged the question of the cause of the seasonal decline of Daphnia in Long Lake. This can be approached through bioenergetics models, which permit quantitative evaluation of distribution and abundance of prey, growth-determining metabolic processes of predators, key environmental factors and related changes in predation pressure within a framework that can be projected through time (Kitchell, Steward \& Weininger, 1977).

Yellow perch probably thrive when both Diaptomus and mid-size Daphnia are plentiful from the time larvae start to feed until the fish become benthivorous (Hansen \& Wahl, 1981; Confer \& Lake, 1987; Mills, Sherman \& Robson, 1989). Previous studies suggest that yellow perch switch from Diaptomus to Daphnia at 25-37 mm total length (Mills \& Forney, 1981; Mills, Confer \& Ready, 1984; Post \& McQueen, 1988). If Daphnia are scarce, perch seek alternate food, including benthos and smaller zooplankton, which causes reduced growth (Mills \& Forney, 1981). Further, fish larvae have a relatively high metabolic rate compared with adults (Post, 1990), and energy stores can be quickly depleted, making them particularly vulnerable to starvation (Lasker, 1975). Starvation has been implicated as a probable cause of recruitment failure if proper food is limited (Hunter, 1981; Miller et al., 1988). Therefore, Daphnia abundance may be critical for successful recruitment.

Maintaining Bythotrephes in laboratory cultures to determine prey consumption rate has been difficult (Burkhardt, 1994; Yurista, 1992), and estimates from the field and laboratory vary widely. In the laboratory, it has been estimated that Bythotrephes can consume $25-30$ prey day ${ }^{-1}$ at maximum (MordukhaiBoltovskaya, 1958). In the field, ingestion rate has been estimated for Lake Huron and Saginaw Bay at 0.4 and $18 \%$ of their body mass daily, respectively (Vanderploeg, Liebig \& Omair, 1993), corresponding to many fewer than 25 prey day ${ }^{-1}$. Bioenergetic analysis based on the carbon budget has yielded results more similar to the maximum, laboratory rate than the field rate. Early instars were estimated to consume $150 \%$ and adults $118 \%$ of their body mass daily (Yurista \& Schulz, 1995).

Modelling trophic interactions requires assumptions regarding prey preference. In the absence of reproducible data on consumption rate and prey preference there has been no resolution of whether either Bythotrephes or fish exert top-down control on Daphnia. While bioenergetics models support arguments that Bythotrephes can suppress Daphnia (Lehman \& Cáceres, 1993; Burkhardt \& Lehman, 1994; Burkhardt, 1991; Lehman \& Branstrator, 1995; Lehman, Bilkovic \& Sullivan, 1997), clearance rates calculated from experiments have been more conservative (Sprules, Riessen \& Jin, 1990; Vanderploeg et al., 1993).

This paper reports our analysis of the interaction between yellow perch, Bythotrephes and Daphnia in Long Lake. The study used a sampling design recommended for age-0 fish-zooplankton interactions (Wanzenböck, Whiteside \& Mehner, 1997). The design integrated size distribution, abundance, and vertical distribution of major zooplankton taxa and production, life history, vertical distribution and development rate of Daphnia with diet, growth, distribution and bioenergetics of fish and Bythotrephes.

\section{Methods}

Site description. Long Lake is a mesotrophic, multiple basin, kettle lake (Lat. $44^{\circ} 43^{\prime} \mathrm{N}$, Long. $85^{\circ} 85^{\prime} \mathrm{W}$, length $6.6 \mathrm{~km}$, width $3.2 \mathrm{~km}$, maximum depth $27 \mathrm{~m}$, mean depth $8.1 \mathrm{~m}$ ) within the Platte River catchment (Fig. 1). About $52 \%$ of Long Lake by area is less than $5 \mathrm{~m}$ in depth. Only $2.9 \%$ of lake surface overlies depths greater than $15 \mathrm{~m}$. Although the littoral zone is large, it is sandy and both submergent and emergent macrophytes are rare. Catchment soils are mostly loamy sands with calciferous bedrock. In 1982, yellow perch, walleye (Stizostedion vitreum vitreum (Mitchill)) and various Centrarchidae were dominant members of the fish community (Michigan Department of Natural Resources, unpublished). 


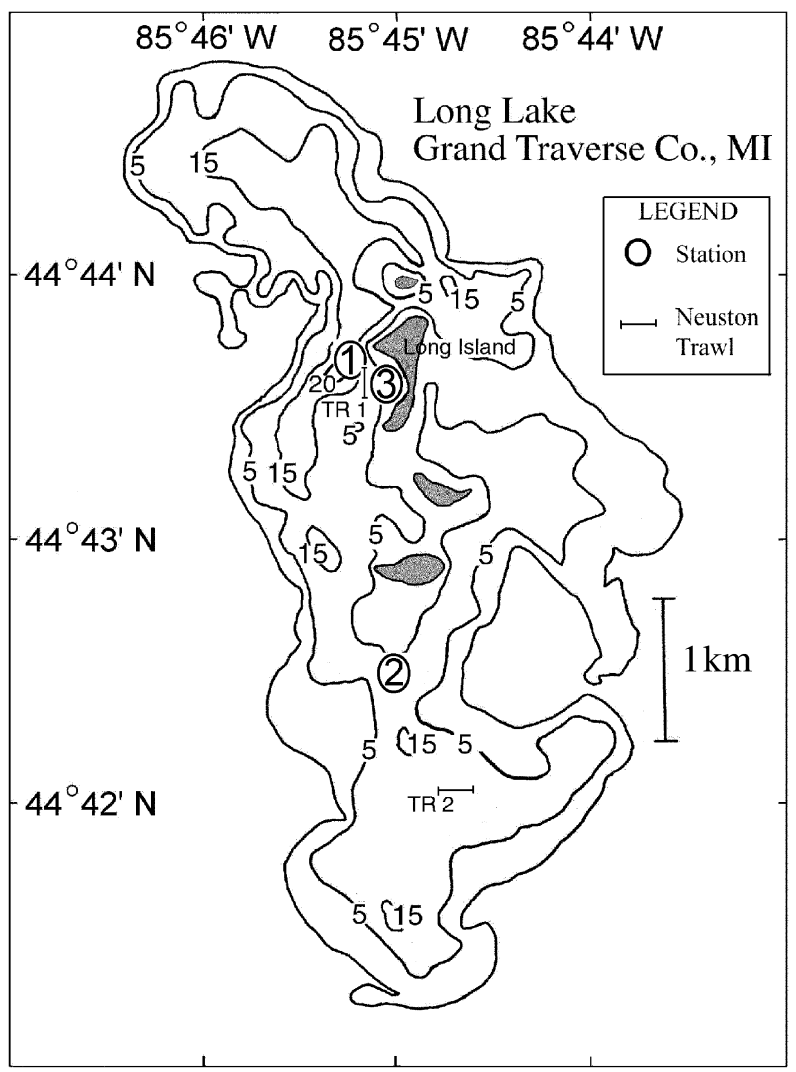

Fig. 1 Bathymetric map of Long Lake, Grand Traverse County, MI. Depth contours in metres.

Field methods. Three stations in Long Lake (Fig. 1) were sampled weekly over a period of 6 months, beginning on 25 April 1998, from April to June, and again in September 1998. Stations were marked and re-visited using GPS navigation (Digital Marine).

Station $1\left(44^{\circ} 43.64^{\prime} \mathrm{N}, 85^{\circ} 45.40^{\prime} \mathrm{W}\right.$, depth $\left.25 \mathrm{~m}\right)$ was the main site for gathering limnological data. Temperature (Whitney Montedoro TC-5), dissolved oxygen (YSI), and photosynthetic active radiation (PAR: LiCor) were recorded at 1 metre intervals, and Secchi depth was also measured. An integrated water sample from surface to $15 \mathrm{~m}$ was collected by tube sampler, then filtered on shore (GF/C) and freeze-dried for subsequent pigment analysis $(90 \%$ $\mathrm{v} / \mathrm{v}$ acetone, extracted fluorescence).

Zooplankton were sampled by plankton net $(30-\mathrm{cm}$ diameter, $153 \mu \mathrm{m}$ aperture, $3: 1$ aspect ratio) in three depth strata: $5 \mathrm{~m}$ to surface, $15 \mathrm{~m}$ to surface, and $24 \mathrm{~m}$ to surface. Four replicate vertical tows were collected for each stratum; replicates were combined and preserved in the field in 50\% ethanol. On shore, zooplankton collections were concentrated by filtering through a Nitex sieve $(130 \mu \mathrm{m})$ and then stored in $90 \%$ ethanol, supplemented in the laboratory with $1 \%$ formalin. Zooplankton were collected on all dates during daylight hours. Additional nocturnal sampling of the same depth strata was conducted on four sampling dates in May. Zooplankton vertical distribution was further assessed using a 15-L Schindler Trap on 9 May and 15 May 1998. Trap samples were taken every $3 \mathrm{~m}$ from 0.5 to $18.5 \mathrm{~m}$ both day and night, condensed, and preserved with 5\% sugar-formalin.

Station $2\left(44^{\circ} 42.17^{\prime} \mathrm{N}, 85^{\circ} 44.96^{\prime} \mathrm{W}\right.$, depth $\left.16 \mathrm{~m}\right)$ was a secondary collection site for zooplankton and chlorophyll $a$. Four replicate zooplankton net tows were collected from $5 \mathrm{~m}$ to surface and $15 \mathrm{~m}$ to surface. On occasions when the vessel was forced off station by high winds, the deeper tow was conducted from $12 \mathrm{~m}$ to surface in order to avoid bottom sediment. Night sampling (23:00 h) in May included two replicate neuston net (mouth $0.31 \times 0.62 \mathrm{~m}$; mesh aperture $333 \mu \mathrm{m}$; bucket screen $130 \mu \mathrm{m}$ ) tows for fish larvae taken at 1-2 $\mathrm{m}$ depth along a 10-m depth contour, towed at $3 \mathrm{~km} \mathrm{~h}^{-1}$ for $200 \mathrm{~m}$ (Fig. 1). The volume filtered was calculated from a General Oceanics digital flowmeter mounted just inside the centre of the net opening. Transects were replicated by recording start and finish points by GPS. Samples were preserved in $50 \%$ ethanol.

At Station $3\left(44^{\circ} 43.60^{\prime} \mathrm{N}, 85^{\circ} 45.08^{\prime} \mathrm{W}\right.$, depth $\left.8 \mathrm{~m}\right)$, four replicate zooplankton tows from $5 \mathrm{~m}$ to surface were conducted during daylight only, and the combined collection was processed as for previous stations. An integrated water sample for chlorophyll $a$ was collected from surface to $5 \mathrm{~m}$. Nocturnal neuston tows were taken parallel to Long Island (Fig. 1) along an 8-m depth contour, using methods as at Station 2.

Laboratory methods. Vertical tows were inspected in full for Bythotrephes, Leptodora, and Chaoborus, and then subsampled quantitatively to count more abundant taxa. Cladocera were recorded to species, copepods to genus. Repeated subsamples were searched until greater than 100 animals were accumulated for each taxon. If it was likely that fewer than 100 animals of any target taxon were present in total, the entire sample was inspected. Subsample counts were corrected by volume ratio to estimate the total in each sample. Individuals of Bythotrephes were removed and assigned an instar by the number of barb pairs. Clutch size for 
parthenogenic females was determined by counting embryos with red or black pigmented eyes. Resting eggs were also recorded. Daphnia clutch size was recorded; loose eggs and embryos were also counted.

Clutch size and body length of all Daphnia in three representative vertical tows, 15 May, 20 June and 20 September, were recorded. Length was measured from the mid-point of the eye to the base of the tail spine using a calibrated ocular micrometer. Presence of eggs or embryos, as well as the clutch size, was recorded for fecund females.

Chlorophyll $a$ was detected by fluorescence using a fluorimeter (Turner TD700) equipped with excitation and emission filters suitable for distinguishing chlorophyll $a$ from phaeopigments. Fluorescence measurements were calibrated to chlorophyll $a$ concentration by reference to acetone blank fluorescence and fluorescence of standard chlorophyll $a$ (Sigma-Aldrich Chemical, St Louis, MI, U.S.A.) diluted in $90 \% \mathrm{v} / \mathrm{v}$ acetone.

Bythotrephes and age-0 yellow perch were removed from neuston tows. Bythotrephes were scored for generation, body length, spine length, sex, clutch size, stage of embryonic development and mass. Distinct generations were determined by following cohorts through time. Length measurements were as defined by Burkhardt (Sullivan \& Lehman, 1998; Fig. 1). Embryonic development was determined by the number of barb pairs and the development stage of the brood sack. First instar (one-barb) and adult female (four-barb stage for animals hatched from resting eggs or three-barb otherwise) animals were either freeze-dried or oven-dried at $60{ }^{\circ} \mathrm{C}$ for $24 \mathrm{~h}$, desiccated at room temperature for $24 \mathrm{~h}$, then weighed ( $\pm 1 \mu \mathrm{g}$; Cahn 29 electrobalance). Body mass or spine mass was determined by weighing the respective tissue. Spines were removed under a dissecting microscope by severing them with a razor at the proximal end of the scleritized spine tissue.

Larval fish were identified to species (Auer, 1982), blotted, weighed $( \pm 0.01 \mathrm{mg}$ wet mass; Mettler H33) and measured ( $\pm 0.25 \mathrm{~mm}$, total length). Gut contents of selected fish were examined, the entire undifferentiated gut was removed, the contents dispersed in a Petri dish, prey items identified to the closest relevant taxon, counted and measured. Copepod length was reported as length of the metasome, Daphnia length was measured from mid-point of the eye to the base of the tailspine, and all other measurable lengths were recorded as the longest dimension of the organism.
The electivity coefficient of Ivlev (1961) was used to compare gut contents to nocturnal mean volumetric abundance of taxa calculated from vertical tows taken $5 \mathrm{~m}$ to surface. Potential values range from -1 , indicating complete rejection of food item, to +1 for exclusive selection of a food item. Copepods unidentifiable because of digestion, but mainly Calanoida, were combined with Diaptomus to calculate a single electivity coefficient.

\section{Daphnia birth and death rate}

Estimation of birth rate. The mean rate of egg development for Daphnia was estimated from the vertical distribution of eggs and embryos and mean stratum temperature. Three strata were considered: 0-5, 5-15 and $15-24 \mathrm{~m}$, based on vertical net collections. Mean inventories $\left(\mathrm{N} \mathrm{m}^{-2}\right)$ of eggs and embryos in the $0-5 \mathrm{~m}$ stratum during Day or Night on each date were calculated directly from the replicate $5 \mathrm{~m}$ tows at Stations 1, 2 and 3. Mean inventories $\left(\mathrm{N} \mathrm{m}^{-2}\right)$ in the 5-15 m stratum during Day or Night on each date were calculated as the difference between $\mathrm{N} \mathrm{m}^{-2}$ from 0 to $15 \mathrm{~m}$ tows and $\mathrm{N} \mathrm{m}^{-2}$ from 0 to $5 \mathrm{~m}$ tows. Mean inventories $\left(\mathrm{N} \mathrm{m}^{-2}\right)$ in the $15-24 \mathrm{~m}$ stratum were calculated as the difference between $\mathrm{N} \mathrm{m}^{-2}$ from 0 to $24 \mathrm{~m}$ tows and $\mathrm{N} \mathrm{m}^{-2}$ from 0 to $15 \mathrm{~m}$ tows.

The relative proportion of eggs and embryos in the various strata, f (eggs), was calculated. Mean temperature in each stratum was calculated from Whitney TC-5 measurements at 1 -m vertical intervals. Development rate $\left(1 / D\right.$, day $\left.^{-1}\right)$ in each stratum was calculated from temperature by (Pastorok, 1978; Edmondson \& Litt, 1982)

$$
1 / D=0.000411 \cdot T^{2}+0.0108 \cdot T^{2}-0.0163
$$

The mean development rate for each vertical distribution (Day or Night) was calculated as

$$
\text { Day- } 1 / D(\text { or Night }-1 / D)=\Sigma(1 / D \cdot f(\text { eggs }))
$$

The Daytime period was calculated as the number of $h$ between sunrise and sunset at the latitude of Long Lake, using the algorithm reported by Fee (1990). The mean development rate was calculated on a $24-\mathrm{h}$ basis by scaling the individual Day and Night (1/D) mean estimates, when both were available:

$$
\begin{aligned}
24 \mathrm{~h}-1 / D= & (1 / D) \text { day } \cdot(\text { day-hours } / 24) \\
& +(1 / D) \text { night } \cdot(\text { night-hours } / 24)
\end{aligned}
$$


In the absence of Night-1/D estimates, the Day-1/D estimates were adopted without modification. Based on the estimated egg development rate, the mean concentration $\left(\mathrm{N} \mathrm{m}^{-3}\right)$ of Daphnia, and the mean egg ratio (E, eggs/female) on each sampling date, birth rate $\left(\mathrm{b}\right.$, day $\left.^{-1}\right)$ was calculated as (Paloheimo, 1974):

$$
b=\ln (E+1) / D
$$

Estimation of death rate. Net intrinsic population growth rate $\left(r\right.$, day $\left.^{-1}\right)$ was calculated from successive estimates of population abundance:

$$
r=\ln [N(t) / N(0)] / \Delta t
$$

Death rate ( $d$, per day) was calculated by difference from:

$$
d=\text { ave- } b-r
$$

where ave- $b$ is the average birth rate (= (initial + final)/2) over the interval used to calculate $r$. The rate of mortality on Daphnia implied by the calculated death rate was estimated as

$$
\text { Daphnia killed } \mathrm{m}^{-3} \text { day }^{-1}=d \text { Daphnia } \mathrm{m}^{-3}
$$

Yellow perch bioenergetics model. The consumption rate of age-0 yellow perch was derived from a bioenergetics model (Kitchell et al., 1974; Kitchell et al., 1977) using the empirical and projected growth rate. The model asserts that per capita growth rate is a function of consumption (C), respiration (R), egestion or faecal loss $(F)$ and excretion or urine loss $(U)$, calculated as per capita intrinsic rates $\left(\right.$ day $\left.^{-1}\right)$ (Kitchell et al., 1977).

$$
\mathrm{d} B / B \mathrm{~d} t=C-(R+F+U)
$$

Consumption is a function of maximum feeding rate, body mass, metabolic rate and temperature (Kitchell et al., 1977; Eq. 2). Respiration is a function of body mass, temperature, activity rate, specific dynamic action and consumption (Kitchell et al., 1977; Eq. 3). Both egestion and excretion are functions of consumption and temperature (Kitchell et al., 1977; Eq. 4). The model includes three adjustments of parameter values to account for differences between adult and young-of-year fish metabolism (Post, 1990; Table 1). Field tests of the model demonstrate that it can describe growth accurately (Rice \& Cochran, 1984; Post, 1990).

The perch model is underdetermined mathematically, and requires a scaling factor, prey availability or $P$, to reconcile the model outcome with empirical data. $P$ represents the proportion (0-1.0) of prey accessible for consumption. In order to be consistent with previous applications of this modelling approach, $P$ was used to scale the ration to fit the observed growth curve. $P$-values were initially fit so that, for each sampling date, the difference between the observed and predicted wet mass was zero. A daily series of $P$-values was then generated using an exponential function fit to the initial $P$-values using a least sum of squares method. This series was used to generate daily growth increments. Population consumption per cubic metre was derived by multiplying the consumption for perch of average individual mass, B, by perch density per cubic metre.

Sampling by neuston net became an ineffective capture method for age-0 yellow perch after 29 May. Perch growth was consequently projected by the

\begin{tabular}{|c|c|c|c|c|c|c|c|c|}
\hline Date & Daphnia & Egg ratio & Birth rate & Diaptomus & Cyclopoids & Chaoborus & Bythotrephes & Clutch size (SD) \\
\hline 25 April & 4290 & 0.15 & 0.019 & 800 & 730 & 0 & 0 & \\
\hline 2 May & 5810 & 0.08 & 0.011 & 310 & 500 & 4 & 4 & - \\
\hline 9 May & 4820 & 0.04 & 0.007 & 4380 & 1100 & 4 & 10 & 8.7 (1.6) \\
\hline 15 May & 4990 & 0.07 & 0.014 & 4010 & 2250 & 10 & 6 & $9.4(2.7)$ \\
\hline 22 May & 4040 & 0.10 & 0.018 & 4040 & 2370 & 1 & 21 & $5.4(0.9)$ \\
\hline 29 May & 2670 & 0.38 & 0.047 & 3420 & 1620 & 14 & 30 & $5.9(1.2)$ \\
\hline 6 June & 380 & 0.60 & 0.080 & 2020 & 560 & & 20 & \\
\hline 12 June & 3 & 0.90 & 0.102 & 1160 & 430 & & 26 & \\
\hline 20 June & 0.1 & 4.96 & 0.295 & 1350 & 340 & & 4 & $3.0(1.4)$ \\
\hline 20 September & 491 & 0.31 & 0.062 & 11900 & 1700 & & 6 & \\
\hline
\end{tabular}

Table 1 Mean volumetric abundance $\left(\mathrm{N} \mathrm{m}^{-3}\right)$ of all taxa in Long Lake, Daphnia egg ratio and birth rate, and Bythotrephes average clutch size, summer 1998. Volumetric abundance was calculated by averaging the deepest diurnal tow available at Stations 1 and 2 for all taxa except Bythotrephes before 6 June. Volumetric abundance for Bythotrephes before June 6 was calculated from nocturnal neuston tows 
model to determine whether perch could have been the primary cause of the decline in Daphnia. The simulation was performed by appending empirical perch weights from Long Lake with weights of Oneida Lake perch from 1976 (Mills \& Forney, 1983). The Oneida Lake time series was appended starting on June 8, the date on which Long Lake perch were projected to reach a mean wet body mass equal to the initial body mass reported in the Oneida Lake time series $(47 \mathrm{mg})$, growing at a rate appropriate to the prey availability measured in late May.

Consumption rate at the population level was determined by multiplying the density of age- 0 fish by the individual consumption expressed in carbon mass. Three limiting assumptions were made: first, there was no fish mortality after 29 May; second, the maximum per capita consumption rate was predicted by the fish body growth trajectory from Oneida Lake; and third, perch consumed only Daphnia. These assumptions assured that the estimated consumption by the fish population would be the maximum plausible. Wet mass was converted to dry mass by a factor of 0.19 (Mills \& Forney, 1983) and dry mass was converted to $C$ by a factor of 0.50 (Salonen et al., 1976; Makarewicz \& Likens, 1979).

Comparing simulated perch predation against expected Daphnia mortality permitted a test of the hypothesis that perch could account for the population decline in D. pulicaria. The number of Daphnia killed $\mathrm{m}^{-3}$ day $^{-1}$ between sample dates was calculated from mean population density of Daphnia multiplied by the per capita death rate for the time interval. To calculate perch consumption in terms of Daphnia eaten $\mathrm{m}^{-3}$, the bioenergetically derived consumption rate was divided by the average weight of prey consumed. First, a hypothetical consumption rate was calculated for perch feeding on juvenile Daphnia (0.8 mm length) and compared with the empirical Daphnia death rate. Secondly, the mean length and weight of Daphnia consumed were calculated by using the empirical length-mass relationship for Daphnia to find the mean body mass necessary to satisfy simultaneously the mortality rate expressed in numbers and in biomass.

The calculated consumption rate was transformed into the death rate $\left(\mathrm{day}^{-1}\right)$ by dividing the predicted number of Daphnia eaten $\mathrm{m}^{-3}$ day $^{-1}$ by total number of Daphnia $\mathrm{m}^{-3}$. The Daphnia population was mod- elled assuming exponential growth, where $r$ was equal to birth rate minus derived death rate based on yellow perch predation.

Bythotrephes bioenergetics model. A bioenergetics model for Bythotrephes was adapted from the set of equations and parameter values reported by Lehman et al. (1997). The model observes mass balance and was used to derive a population level consumption rate by providing empirical values for temperature, neonate and adult female mass and population density. Total predation is calculated as a function of growth $(\mathrm{d} C / \mathrm{d} t)$, respiration $(R)$, ingestion efficiency (IE) and assimilation efficiency (AE). Respiration is an exponential function of temperature, growth is an exponential function of age. Ingestion efficiency is the ratio of prey biomass ingested to the biomass of prey killed. Assimilation efficiency is the fraction of prey biomass ingested that is not subsequently egested. Parameters and equations were unaltered for model implementation.

The abundance-weighted mean development rate was calculated from the proportion of Bythotrephes found in the $0-5,5-15$ and $15-24 \mathrm{~m}$ strata and the amount of time spent in each stratum:

$$
\begin{aligned}
d_{\text {Mean }}= & \Sigma\left[\mathrm{D}(T)_{i} f_{i}\right]\left(\text { day h/24) }+\Sigma\left[D(T)_{i} f_{i}\right]\right. \\
& (\text { night h/24) }
\end{aligned}
$$

where $D(T)_{i}$ is development as function of stratum temperature in stratum $i, f_{i}$ the frequency of Bythotrephes found in stratum $i$, and day $h$ the number of $h$ between sunrise and sunset for a particular sampling date. Because development and respiration are both nonlinear functions of temperature, the mean temperature experienced by a population does not predict accurately the mean metabolic rate. Thus, equivalent mean daily temperature referenced to development rate (Tequiv) of Bythotrephes was calculated. 'Tequiv' is the equivalent temperature required to reproduce the weighted mean development rate for the population, calculated as in Eq. 9. Tequiv values were used to estimate a conservative bound for Bythotrephes predation.

A similar test to that carried out for yellow perch was performed, comparing simulated Bythotrephes predation against expected Daphnia mortality in order to test the hypothesis that Bythotrephes could account for the population decline in D. pulicaria. Again, for 
simplicity and reference calculation, we assumed that the predator, Bythotrephes, consumed only Daphnia.

\section{Results}

Limnological conditions. Long Lake warmed gradually from 25 April to 29 May (Fig. 2). The warming trend was interrupted temporarily between 29 May and 6 June, when a strong mixing episode cooled and deepened the epilimnion. During these 2 weeks, average weekly air temperature fell from $17.7^{\circ} \mathrm{C}$ the previous week to $12.6{ }^{\circ} \mathrm{C}$ and $16.2^{\circ} \mathrm{C}$, respectively. Subsequently, the lake continued to become warm. Dissolved oxygen reciprocated the pattern exhibited by temperature over the sampling period (Fig. 2). By 29 May, the depths of the lake were becoming anoxic, but the mixing episode replenished them with oxygen. By 20 September, the lake had become anoxic below $15 \mathrm{~m}$.

Chlorophyll $a$ increased throughout the summer from 0.31 (25 April, Station 2) to $1.83 \mu \mathrm{g} \mathrm{L}^{-1}$ (20 September, Station 2). No consistent pattern was observed between stations. Secchi depth was maximal on 9 May. The depth at which $1 \%$ of surface PAR remained from 24 April to 15 May was approximately $24 \mathrm{~m}$. On 6 June, after the cooling episode, Secchi depth and the limit of penetration of $1 \%$ surface PAR declined.

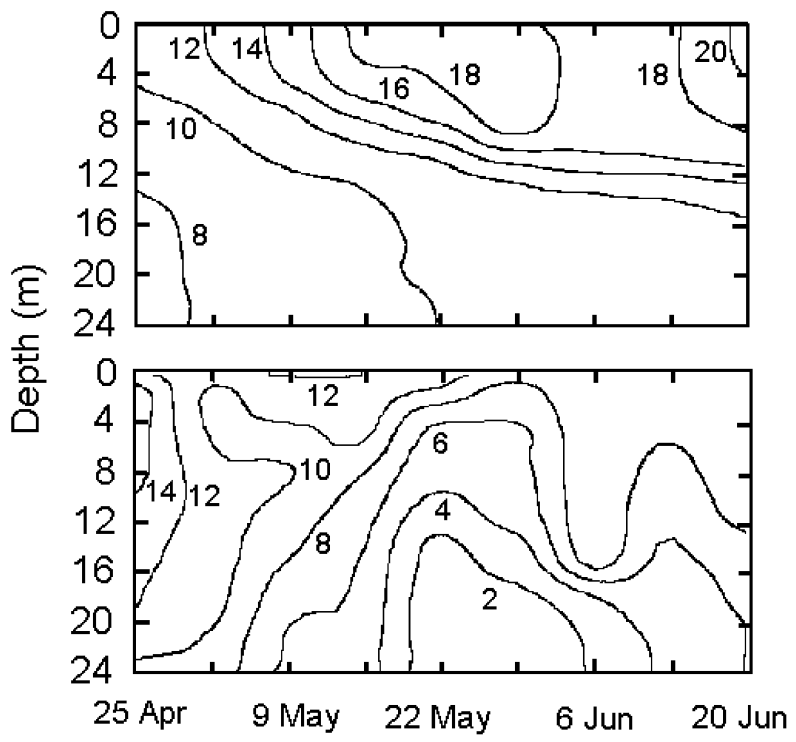

Fig. 2 Isopleths of temperature (top) and dissolved oxygen (below) of Long Lake 1998.

(C) 2001 Blackwell Science Ltd, Freshwater Biology, 46, 759-775
Zooplankton community and dynamics. Long Lake was populated mainly by D. pulicaria, Diaptomus minutus Lilljeborg and Diaptomus oregonensis Lilljeborg, Cyclopoida and Chaoborus. In September 1998, other taxa present at low density included Bosmina longirostris (O.F. Mueller), Diaphanosoma birgei Korinek, Leptodora kindtii Focke and various rotifers. In samples collected in September 1997, two specimens of Daphnia ambigua Scourfield were found and Diaptomus dominated the water column. Rare taxa in 1997 included Cyclopoida, Epischura lacustris S.A. Forbes, D. birgei, B. longirostris, Chydorus, Ceriodaphnia and Asplanchna.

Comparisons of abundance were performed using paired $t$-tests on logarithmically transformed data from vertical tows. If the abundance in the sample was zero for one or both members of the pair, the data were excluded. For all inventory data $\left(\mathrm{N} \mathrm{m}^{-2}\right)$ from 0 to $5 \mathrm{~m}$ vertical tows, results were statistically indistinguishable among all stations. Furthermore, diurnal 0-15 $\mathrm{m}$ tows from Stations 1 and 2 were indistinguishable for all dates. Egg ratio data for Daphnia from 0 to $15 \mathrm{~m}$ and $0-24 \mathrm{~m}$ tows on dates when both strata were sampled were also indistinguishable. A significant difference was found between daytime and nighttime inventories calculated from 0 to $15 \mathrm{~m}$ vertical tows (Stations 1 and 2 combined) for both cyclopoid copepods and Chaoborus $(P=0.025$ and $P=0.007$, respectively). A significant difference was also found between the inventories calculated from 0 to $15 \mathrm{~m}$ and 0-24 m vertical tows for cyclopoids $(P=0.047)$.

Mean concentrations (combined day and night) of Diaptomus C1-C6, cyclopoid C1-C6, and Bythotrephes were indistinguishable between 0 and $15 \mathrm{~m}$ and 0-24 m collections. The mean concentration of Daphnia $\left(\mathrm{N} \mathrm{m}^{-3}\right)$ estimated from 0 to $24 \mathrm{~m}$ tows was greater than that estimated from 0 to $15 \mathrm{~m}$ tows $(P=0.031)$, on all dates except 29 May, when concentration was indistinguishable between depth strata. This result is confounded by diel migration, because all 0-24 m tows were daytime collections except 29 May, for which both day and night collections existed.

Based on the statistical inferences and conclusions, abundance for each taxon was estimated using the following data groupings. All diurnal $0-5 \mathrm{~m}$ vertical tows inventories from Stations 1, 2 and 3 were pooled by dates, as were nocturnal $0-5 \mathrm{~m}$ tows for Stations 1 and 2. All diurnal 0-15 m inventories were pooled by date, and nocturnal $0-15 \mathrm{~m}$ inventories were also 
pooled by date. The diurnal and nocturnal 0-24 m concentration estimates for 29 May were pooled. Mean concentrations $\left(\mathrm{N} \mathrm{m}^{-3}\right)$ were estimated from 0 to $24 \mathrm{~m}$ tows when possible. In the absence of a 0-24 $\mathrm{m}$ tow, we pooled diurnal $0-15 \mathrm{~m}$ tows from Stations 1 and 2. On 25 April, concentrations were estimated from the only data available, 0-15 m diurnal vertical tows at Stations 1 and 2 .

Daphnia pulicaria was numerically dominant $\left(4000 \mathrm{~m}^{-3}\right)$ from 25 April to 22 May (Table 1), Diaptomus was dominant thereafter. Daphnia declined by about one half the following week and by 12 June had become rare $\left(3 \mathrm{~m}^{-3}\right)$. By September, Daphnia remained rare. The highest birth rate was observed on 20 June. Potential bias in birth rate estimates from egg predation or egg inviability was undetectable; there were no statistical differences $\left(\chi^{2}\right.$ analysis, $P=0.1$ ) in egg:embryo ratio among all dates (mean proportion embryos $=0.20, \mathrm{SD}=0.03, n=9$ dates) except for 12 June, when the average proportion of
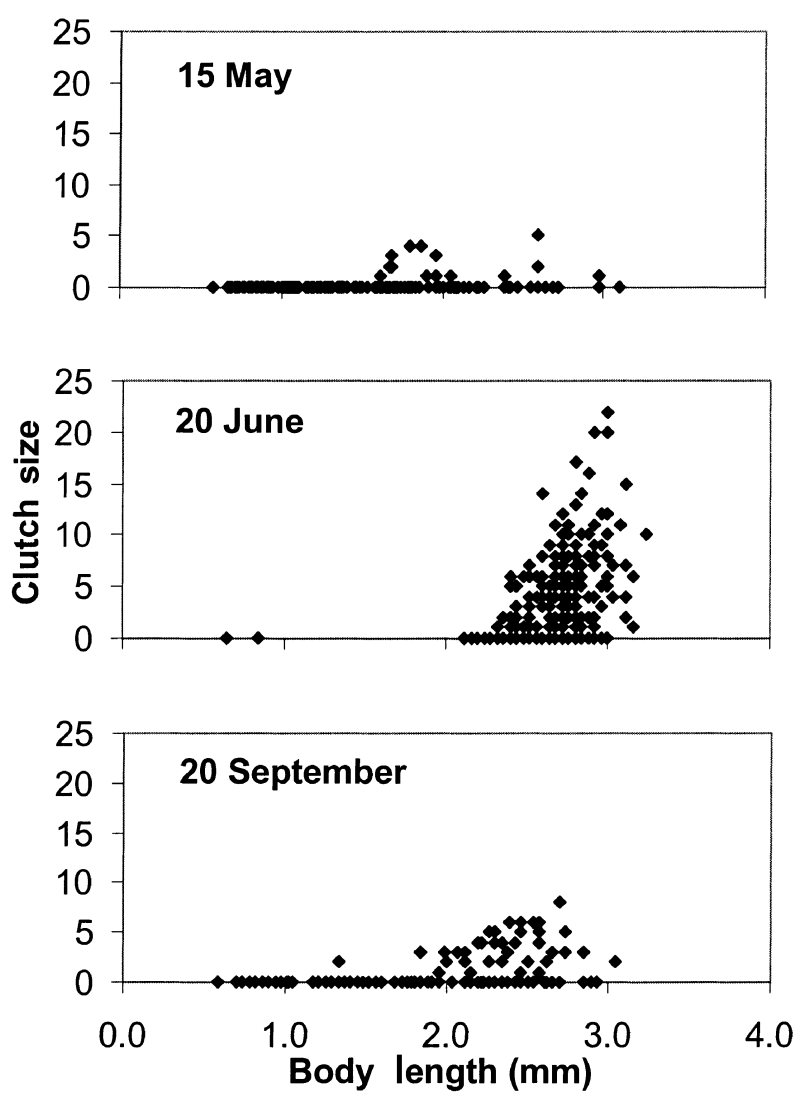

Fig. 3 Daphnia body length and clutch size measured in number of eggs or embryos per total number of females for 15 May, 20 June and 20 September. embryos was elevated (0.29). Daphnia clutch size also changed over time (Fig. 3). Comparison of 15 May and 20 June samples indicated fewer juveniles present on 20 June, despite larger clutches in existing females. Comparison of 15 May and 20 September samples also shows a larger proportion of juveniles on 15 May, although the 20 September sample contained a larger proportion of juveniles than did 20 June.

Three trends were observed in the size distribution of Daphnia. First, average length increased significantly from 15 May to 20 June as the dominant stage switched from juveniles to adults (Table 2). The average size of Daphnia on 15 May was $1.44 \mathrm{~mm}$, on 20 June it was $2.65 \mathrm{~mm}$. Secondly, length distribution changed from unimodal to bimodal as juveniles disappeared from the population (Fig. 4). Thirdly, the lesser of the two modes shifted down in size, as juveniles were increasingly scarce, from 1.0 (6 June) to $0.8 \mathrm{~mm}$ (20 June).

As juvenile Daphnia were removed, the proportion of females bearing eggs increased, which increased the overall egg : female ratio (Table 1). The proportion of females bearing ephippia was 0.00 from 25 April to 22 May, but increased to 0.08 on 29 May then 0.12 on 6 June, and fell again to 0.04 and 0.00 on 12 June and 20 June, respectively, suggesting an episode of food limitation.

Diaptomus and cyclopoid copepods declined coincident with Daphnia during late May and June (Table 1). Unfortunately, because adults were rare in samples throughout May, it was not possible to calculate birth and death rates or clutch size variation for these populations as for Daphnia.

Zooplankton diel migration. Diel vertical migration by Daphnia was detected on 9 and 15 May (Fig. 5) by Schindler trap. By day, the majority of Daphnia

Table 2 Minimum, maximum and mean length of D. pulicaria in Long Lake 1998

\begin{tabular}{lllllll}
\hline & \multicolumn{2}{l}{ Length } & & & \\
\cline { 2 - 5 } Date & $\begin{array}{l}\text { Minimum } \\
(\mathrm{mm})\end{array}$ & $\begin{array}{l}\text { Maximum } \\
(\mathrm{mm})\end{array}$ & $\begin{array}{l}\text { Mean } \\
(\mathrm{mm})\end{array}$ & SE & $n$ \\
\hline 15 May & 0.57 & 3.11 & 1.44 & 0.08 & 302 \\
22 May & 0.75 & 2.51 & 1.55 & 0.13 & 140 \\
29 May & 0.71 & 3.04 & 1.84 & 0.16 & 143 \\
6 June & 0.71 & 2.06 & 1.72 & 0.06 & 283 \\
20 June & 0.64 & 3.24 & 2.65 & 0.14 & 343 \\
20 September & 0.64 & 3.00 & 1.64 & 0.10 & 162 \\
\hline
\end{tabular}

(C) 2001 Blackwell Science Ltd, Freshwater Biology, 46, 759-775 

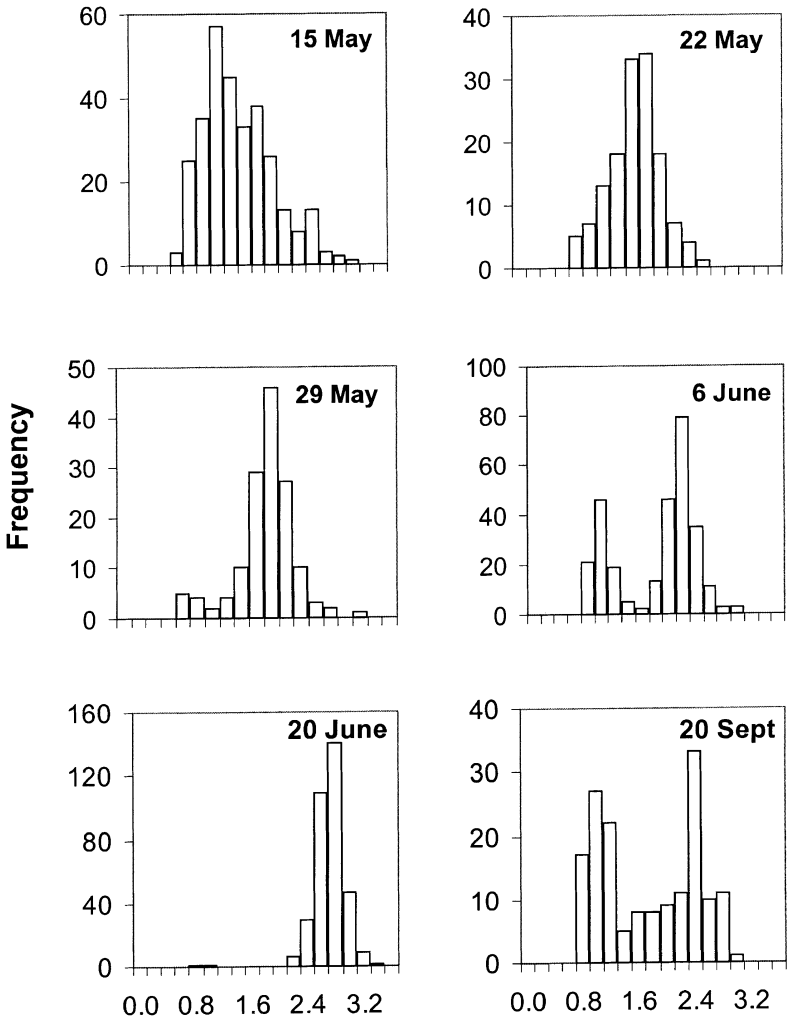

\section{Size $(\mathbf{m m})$}

Fig. 4 Size distribution of D. pulicaria in Long Lake from 15 May to 20 June 1998.

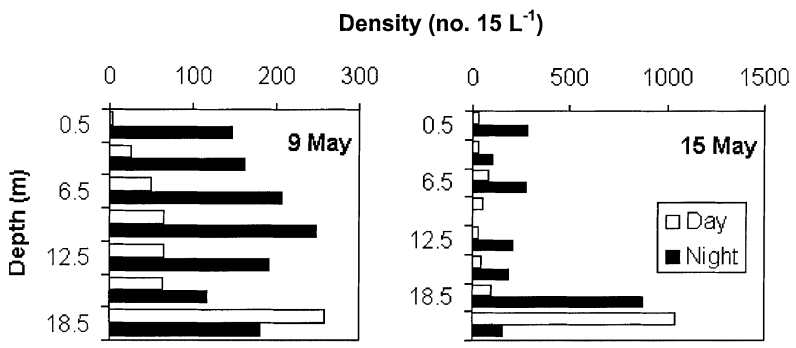

Fig. 5 Diel migration patterns in Daphnia from 9 and 15 May. Abundance is given as number of zooplankton per $15 \mathrm{~L}$.

resided in the deepest strata sampled, $18.5 \mathrm{~m}$. On 15 May, more than 1000 Daphnia were in the $18.5 \mathrm{~m}$ sample. Collections from shallower water also contained less than 100 animals. Nocturnal samples show migration up the water column, with the majority of Daphnia between 8 and $12 \mathrm{~m}$. Similarly, daytime samples from 9 May show the distribution of Daphnia to be highly stratified. Nocturnal samples on 9 May indicate a uniform distribution in the water column. Fecund females on 9 and 15 May demon- strated the same migration patterns as the rest of the population.

Bythotrephes were too rare to be sampled by Schindler trap. Instead, migration patterns were observed in vertical tows. The population was concentrated below $5 \mathrm{~m}$ during daytime sampling. From 15 May to 20 September, over $90 \%$ of Bythotrephes were found below $5 \mathrm{~m}$, except on 29 May, when over $80 \%$ were found below $5 \mathrm{~m}$. During night, particularly in early May, a greater abundance of Bythotrephes was found in shallow water. On 9 May, 33\% of the population was found below $5 \mathrm{~m}$. By 29 May, $82 \%$ remained below $5 \mathrm{~m}$, even at night. Bythotrephes became confined to deeper strata through the summer and eventually became scarce, except at Station 1. Daphnia were generally distributed deeper than Bythotrephes during the day, but demonstrated diel migration. Thus, their distributions overlapped more extensively at night.

Clear water phase. Historical Secchi disk records (Fig. 6) show that from 1992 to 1998, vernal Secchi depths of $8-10 \mathrm{~m}$ were common. Typically, the clear water phase began in late April. The maximum Secchi depth measured was 18.9 m (1997). In 1998, an early clear

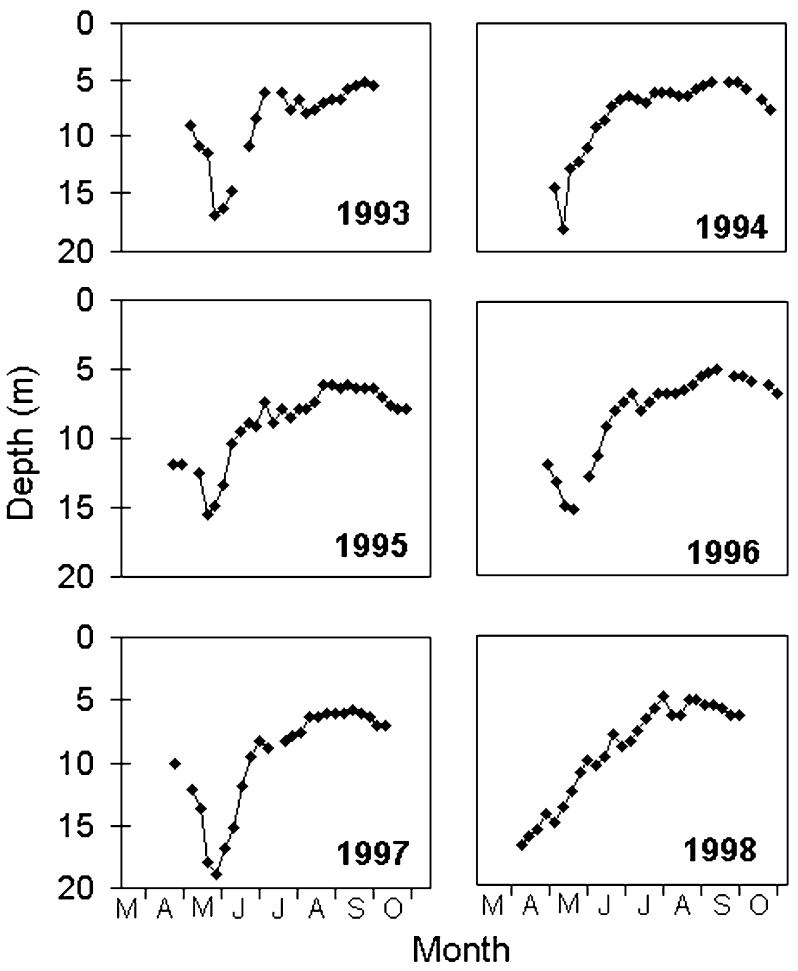

Fig. 6 Secchi disk profiles for Long Lake 1993-98. 
water phase occurred, with a maximum depth of $16.8 \mathrm{~m}$ on 25 April, approximately 3 weeks ahead of the record in 1993 and 1996, when maximum Secchi disk depth was similar $(17.1 \mathrm{~m}$ and $15.1 \mathrm{~m}$, respectively) on 29 May. On 20 June, chlorophyll $a$ increased above $1.0 \mu \mathrm{g} \mathrm{L}^{-1}$, whereas in previous weeks it had been approximately $0.6 \mu \mathrm{g} \mathrm{L}^{-1}$. Also, Secchi depth decreased to less than $10 \mathrm{~m}$ and Daphnia became extremely rare. Based on these distinct, correlative changes, we defined the clear water phase in Long Lake as the period with Secchi transparency exceeding $10 \mathrm{~m}$. Thus, average length of the clear water phase from 1993 to 1998 was 8 weeks.

Abundance, growth and diet of age-0 yellow perch. Age-0 yellow perch were taken in neuston samples from 2 to 29 May. Perch on 2 and 9 May were at hatching length (5-6 mm total length); by 29 May, average total length increased to $14.7 \mathrm{~mm}$ (Table 3). Average wet mass per yellow perch increased exponentially from 0.3 to $18.6 \mathrm{mg}$ by 29 May (Table 3). The greatest density of yellow perch was observed on 16 May, just after the major hatching period, at $2.21 \mathrm{~m}^{-3}$ (Table 3), and declined afterwards to approximately $0.2 \mathrm{~m}^{-3}$ by 22 May.

Table 3 Mean length, wet mass and volumetric abundance of age-0 yellow perch in Long Lake

\begin{tabular}{|c|c|c|c|c|c|c|}
\hline Date & $\begin{array}{l}\text { Length } \\
(\mathrm{mm})\end{array}$ & SD & $\begin{array}{l}\text { Wet } \\
\text { mass } \\
(\mathrm{mg})\end{array}$ & $\mathrm{SD}$ & $n$ & $\begin{array}{l}\text { Average } \\
\text { abundance } \\
\left(\mathrm{N} \mathrm{m}^{-3}\right)\end{array}$ \\
\hline 2 May 98 & 6.00 & - & 0.3 & - & 1 & 0.01 \\
\hline 9 May 98 & 6.62 & 0.66 & 0.7 & 0.2 & 101 & 0.57 \\
\hline 15 May 98 & 8.28 & 1.39 & 1.4 & 0.9 & 196 & 2.21 \\
\hline 22 May 98 & 10.39 & 2.44 & 5.0 & 3.5 & 18 & 0.17 \\
\hline 29 May 98 & 14.66 & 3.07 & 18.6 & 14.8 & 27 & 0.20 \\
\hline
\end{tabular}

Table 4 Mean length of age-0 yellow perch sampled for gut contents $(n=5)$, number of prey found in the digestive tract, length of prey and electivity coefficient for 29 May

\begin{tabular}{lllll}
\hline $\begin{array}{l}\text { Average } \\
\text { perch length } \\
(\mathrm{mm})\end{array}$ & $\begin{array}{l}\text { Prey } \\
\text { in gut }\end{array}$ & $\begin{array}{l}\text { Average } \\
\text { number } \\
\text { in gut }\end{array}$ & $\begin{array}{l}\text { Average } \\
\text { length } \\
(\mathrm{mm})\end{array}$ & $\begin{array}{l}\text { Ivlev's } \\
\text { electivity } \\
\text { coefficient }\end{array}$ \\
\hline 17.1 & Copepod & 22.4 & 0.41 & Combined \\
& Diaptomus & 11.8 & 0.53 & 0.50 \\
& Daphnia pulicaria & 1.2 & 1.25 & -0.75 \\
& Cyclopoid & 1.0 & 0.48 & -0.85 \\
& Others & 0.4 & 1.00 & $\mathrm{n} / \mathrm{c}$ \\
\hline
\end{tabular}

' $\mathrm{n} / \mathrm{c}$ ' indicates value not calculated.
On 29 May, yellow perch $15-21 \mathrm{~mm}$ in size favoured Diaptomus and other copepods as prey (Table 4). These taxa composed over $80 \%$ of all prey found in the stomachs. Daphnia pulicaria were rarely found $(3.3 \%)$ compared with unidentifiable copepods (60.9\%) and Diaptomus (32.1\%). Based on Ivlev's equation, age-0 yellow perch showed strong selection against Daphnia, cyclopoids and Chaoborus and strong selection for Diaptomus (Table 4). Diaptomus and other copepods found in perch guts had mean lengths of 0.41 and $0.53 \mathrm{~mm}$, respectively. Daphnia were the largest food items, averaging $1.25 \mathrm{~mm}$, but still significantly smaller than the average Daphnia size, $1.84 \mathrm{~mm}(P=0.006)$.

Mass, abundance and distribution of Bythotrephes. Individuals of the one-barbed, first (G1) generation of Bythotrephes, hatched from over-wintered resting eggs, were an order of magnitude smaller in mass than 1barbed Bythotrephes of the third (G3) generation (Table 5). Compared with Bythotrephes of the Great Lakes, dry mass by instar of Bythotrephes in 1997 was intermediate between those sampled in Lake Erie and Lake Huron (Bilkovic \& Lehman, 1997), and more variable within instars (Table 5). Maximum body

Table 5 Comparison of the mean total dry mass of Bythotrephes from the Great Lakes in 1993 (Bilkovic \& Lehman, 1997; Table 1) with that in Long Lake by stage (S) or instar (I), and generation $(G)$ when known

\begin{tabular}{|c|c|c|c|c|}
\hline Lake & Stage & $n$ & $\begin{array}{l}\text { Dry mass } \\
(\mu \mathrm{g})\end{array}$ & $\begin{array}{l}\text { CV } \\
(\%)\end{array}$ \\
\hline \multirow[t]{4}{*}{ Long Lake 1997} & S1 & 22 & 63.1 & 47.4 \\
\hline & S2 & 17 & 114.3 & 30.3 \\
\hline & S3 & 5 & 144.2 & 14.8 \\
\hline & S4 & 4 & 306.5 & 13.2 \\
\hline \multirow[t]{4}{*}{ Long Lake 1998} & I1 (G1) & 116 & 1.9 & 31.6 \\
\hline & I4 (G1) & 46 & 64.4 & 33.4 \\
\hline & I1 (G3) & 60 & 24.9 & 102.0 \\
\hline & I3 (G3) & 99 & 207.7 & 36.9 \\
\hline \multirow[t]{4}{*}{ Lake Erie } & $\mathrm{S} 1$ & 18 & 42.6 & 5.4 \\
\hline & $\mathrm{S} 2$ & 31 & 97.8 & 4.1 \\
\hline & S3 & 11 & 120.8 & 3.1 \\
\hline & $\mathrm{S} 4$ & 12 & 202.8 & 5.8 \\
\hline \multirow[t]{4}{*}{ Lake Huron } & $\mathrm{S} 1$ & 8 & 78.0 & 17.8 \\
\hline & S2 & 32 & 174.3 & 4.9 \\
\hline & S3 & 14 & 268.2 & 10.1 \\
\hline & $\mathrm{S} 4$ & 36 & 506.7 & 4.3 \\
\hline \multirow[t]{2}{*}{ Lake Michigan } & $\mathrm{S} 1$ & 10 & 133.9 & 4.0 \\
\hline & S4 & 6 & 621.6 & 9.7 \\
\hline
\end{tabular}

(C) 2001 Blackwell Science Ltd, Freshwater Biology, 46, 759-775 


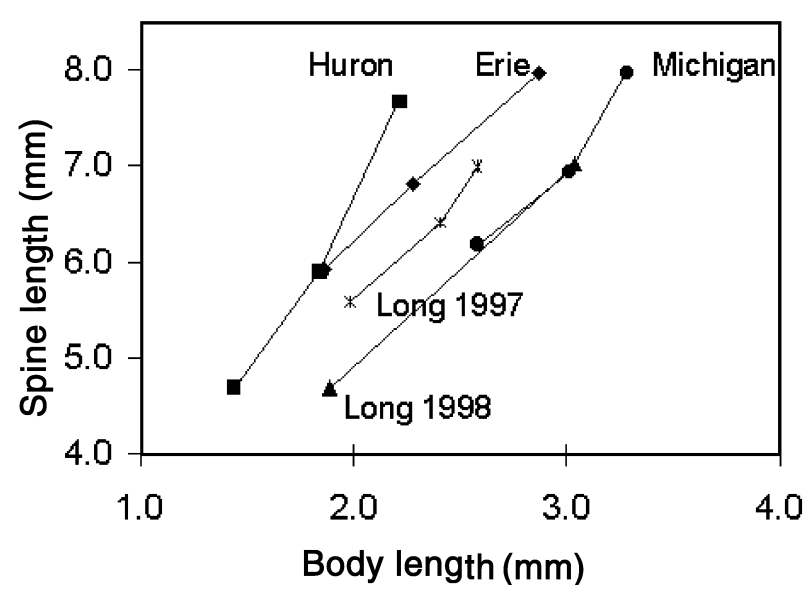

Fig. 7 Comparison of mean body lengths and spine lengths of Bythotrephes by instar stage from Lakes Erie, Huron, Michigan in 1996 (Sullivan \& Lehman, 1997) and Long Lake in 1997 and 1998.

weights are reached at late brood stage, stage 4 (Bilkovic \& Lehman, 1997), when the four-barb or three-barb females are near parturition and are carrying embryos at the black-eye stage of development. G1, stage 4 females weighed $89.4 \mu \mathrm{g}$ on 15 May. By 21 June, G3, stage 4 females weighed $378.5 \mu \mathrm{g}$.

Morphology of Long Lake Bythotrephes was intermediate between populations in Lakes Erie and Michigan (Fig. 7). Total spine lengths were shorter, $7 \mathrm{~mm}$, than those found in the Great Lakes, $8 \mathrm{~mm}$. Spine length thus does not appear to be constant among all lakes, but ratio of body length to spine length for 3-barb animals produced by parthenogenesis appears to be constant at about 0.40 .

Abundance of Bythotrephes increased from $4 \mathrm{~m}^{-3}$ (2 May) to a maximum of $30 \mathrm{~m}^{-3}$ on 29 May, and subsequently declined (Table 1). In May, neuston tows taken near the surface at night yielded estimates of Bythotrephes abundance that exceeded concentrations in vertical tows at deep stations by factors ranging from 100 to 3 . Vertical tows revealed that, in May, Bythotrephes was initially found in the warm upper epilimnion, which then contributed to a large proportion of total lake volume. In June, Bythotrephes effectively vanished from shallow water and so vertical tows in deep water were more representative; data indicated that Bythotrephes were abundant only in the lower strata. Accordingly, we calculated Bythotrephes abundance from the large volume neuston collections during May, and then from vertical net collections in June.

Bioenergetics model for P. flavescens. During May, perch growth averaged 0.24 day $^{-1}$, ranging from 0.12 on 2 May to 0.34 on 15 May. Predation simulations comparing derived consumption rates to hypothetical prey size indicated that perch feeding on juvenile Daphnia $0.8 \mathrm{~mm}$ in length could not account for Daphnia mortality between 22 May and 6 June (Table 6). To account for the numbers of Daphnia killed in May, perch would have had to consume only very small Daphnia from 15 to 22 May, and only large

Table 6 Results of predation simulations with age-0 yellow perch and Bythotrephes bioenergetics models. ' $\Sigma$ Predation' = population level consumption calculated from the models, 'Daphnia death rate' = number of Daphnia expected to die based on birth and death rate analyses, 'Consumption' $=$ number of $0.8 \mathrm{~mm}$ length Daphnia consumed by each predator, 'Daphnia mass' = mean mass of individual Daphnia consumed by each predator feeding at Daphnia mortality level, 'Daphnia length' = mean length of individual Daphnia consumed by each predator feeding at Daphnia mortality level

\begin{tabular}{|c|c|c|c|c|c|}
\hline Time interval & 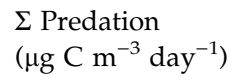 & $\begin{array}{l}\text { Daphnia death rate } \\
\left(\mathrm{N} \mathrm{m}^{-3} \text { day }^{-1}\right)\end{array}$ & $\begin{array}{l}\text { Consumption } \\
\left(\mathrm{N} \mathrm{m}^{-3} \text { day }^{-1}\right)\end{array}$ & $\begin{array}{l}\text { Daphnia mass } \\
(\mu \mathrm{g} \mathrm{C})\end{array}$ & $\begin{array}{l}\text { Daphnia length } \\
(\mathrm{mm})\end{array}$ \\
\hline \multicolumn{6}{|c|}{ Age-0 perch bioenergetics model } \\
\hline 15-22 May & 649 & 207 & 563 & 0.3 & 0.53 \\
\hline 22-29 May & 143 & 307 & 124 & 2.1 & 0.97 \\
\hline 29 May-6 June & 455 & 470 & 395 & 1.0 & 0.77 \\
\hline 6-12 June & 1080 & 169 & 937 & 0.2 & 0.43 \\
\hline 12-20 June & 1956 & 1 & 1697 & 0.0 & 0.07 \\
\hline \multicolumn{6}{|c|}{ Bythotrephes bioenergetics model } \\
\hline 15-22 May & 213 & 207 & 184 & 0.97 & 0.76 \\
\hline 22-29 May & 695 & 307 & 603 & 0.44 & 0.59 \\
\hline 29 May-6 June & 755 & 470 & 655 & 0.62 & 0.66 \\
\hline 6-12 June & 515 & 169 & 447 & 0.33 & 0.54 \\
\hline 12-20 June & 362 & 1 & 314 & 0.00 & 0.12 \\
\hline
\end{tabular}




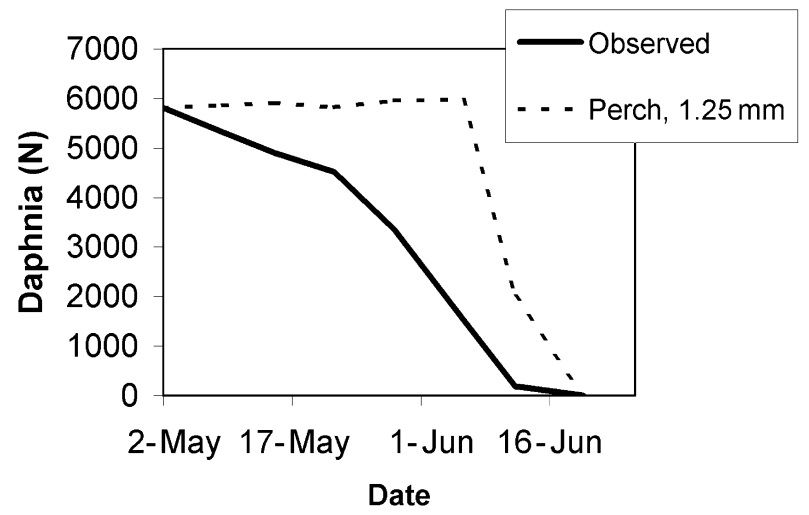

Fig. 8 Simulated population decline of Daphnia with the assumption that age-0 yellow perch consumed only Daphnia $1.25 \mathrm{~mm}$ in length.

juvenile Daphnia from 22 to 29 May. By 6 June, perch would have to consume Daphnia smaller than Daphnia size at birth in order to account numerically for Daphnia mortality.

Thus, the only credible model for top-down control of Daphnia by yellow perch is that perch exclusively consumed juvenile Daphnia after 29 May. If perch were consuming only Daphnia of the mean size actually found in their guts on 29 May $(1.25 \mathrm{~mm})$, no decline in Daphnia would have been observed until 10 June (Fig. 8). Daphnia death rates, calculated on the assumption that perch were feeding on Daphnia $1.25 \mathrm{~mm}$ in length, suggested that the Daphnia population should have remained constant or increased slightly until 10 June, at which point a sharp decline would have occurred.

During 1998, $P$-values were less than 0.2 until 12 May. The $P$-value remained low during the entire sampling period, but increased to 0.35 for fish growing from 22 to 29 May.

Bioenergetics model for Bythotrephes. The observed dry mass of three-barb females carrying embryos without pigmented eyes was compared with the dry mass predicted by the bioenergetics model. The first (G1) generation's growth trajectory was not modelled accurately by the bioenergetics model; average predicted mass was $77 \%$ of that observed. For subsequent generations (G2, G3), however, the model appears to provide relatively accurate predictions; predicted mass was $108 \%$ of that observed.

Calculated prey consumption by Bythotrephes was the greatest from 29 May to 12 June and greater than the Daphnia death rate for all dates (Table 6). The maximum daily value for total predation was $1020 \mu \mathrm{g} \mathrm{C} \mathrm{m}^{-3} \mathrm{day}^{-1}$ on 29 May. The consumption rate per unit biomass was intermediate between that calculated by Yurista \& Schulz (1995) and Vanderploeg et al. (1993), averaging 0.93, 0.78 and 0.64 day $^{-1}$, respectively, for one, two and three-barb instars from 2 May to 20 June.

Calculated mean length of Daphnia consumed (Table 6) suggests Bythotrephes predation was consistent with the observed size distribution of Daphnia. The bimodal distribution (Fig. 4) suggests that Bythotrephes were feeding on animals $0.8-1.0 \mathrm{~mm}$ in length, less than the mean length of Daphnia for all dates sampled. Assuming Bythotrephes was consuming the available food, modelled by setting predation from Bythotrephes equal to the total number of Daphnia dying week ${ }^{-1}$, the calculated mean length of Daphnia consumed from 15 May to 12 June (Table 6, column 5) was consistent with the selected sizes inferred from the field data. After 12 June, Daphnia abundance and total mortality were too low to support Bythotrephes' requirements for prey.

\section{Discussion}

Length data and egg ratio data evaluated together suggest that Long Lake Daphnia populations were affected by predation throughout most of the study. Daphnia size data suggest severe, size selective predation on juveniles during late May and early June 1998 (De Bernardi \& Guissani, 1975; Zaret, 1980). By 20 June, Daphnia in the size range preferred both by Bythotrephes and age-0 yellow perch were absent (Hansen \& Wahl, 1981; Burkhardt \& Lehman, 1994). The size distribution of Daphnia indicated that mortality was concentrated in the smallest individuals. It is therefore likely that gape-limitation was a factor in Daphnia predation. Birth rate and average clutch size increased in mid-June while the Daphnia populations decreased, indicating that an accelerated death rate was crucial in the dynamics. Ephippial production by Daphnia increased in late May and early June, indicating the population was food-stressed at the start of its decline. The proportion of females that became gametogenic was small (maximum $=0.12$ on 6 June, dropping back to zero by 20 June), however, and in any event does not account for the strikingly bimodal size distribution and marked increase in partheno- 
genic birth rate. Thus, the most probable explanation for the Daphnia decline was predation by age-0 fish or an invertebrate, not starvation or predation by adult fish.

Diet analysis suggests that age- 0 perch could not be a primary cause of Daphnia decline in Long Lake. Gut contents of yellow perch on 29 May were dominated by Diaptomus, with few Daphnia present. Perch showed strong electivity for Diaptomus and strong electivity against Daphnia. Thus, diet data suggest that age-0 yellow perch were not a major factor in the decline of Daphnia. Similarly, copepods composed over $90 \%$ of the diet in Oneida Lake, New York for yellow perch of $15 \mathrm{~mm}$ length (Wahl et al., 1993), and cyclopoids composed $64.2 \%$ while Daphnia only composed $0.5 \%$ of the diet of $17 \mathrm{~mm}$ yellow perch in Lake St George, Ontario (Post \& McQueen, 1988). The relative availability of suitably sized prey may explain the preference of perch. Hansen \& Wahl (1981) found that Oneida Lake yellow perch under $28 \mathrm{~mm}$ show strong preference for Daphnia $0.5 \mathrm{~mm}$ in length, similar to the mean size of Diaptomus and copepods consumed by perch in Long Lake. No Daphnia found in the gut of sampled yellow perch was so small, most probably because of the increasing rarity of juvenile Daphnia.

Bioenergetics modelling indicated age-0 yellow perch density was too low, and observed growth too small, to permit perch to cause the decline in Daphnia, even if perch ate Daphnia exclusively. Population modelling of Daphnia, with the assumption that perch were eating Daphnia of the mean size $(1.25 \mathrm{~mm})$ estimated for 29 May, indicated that the Daphnia decline began too early in the season to attribute it to predation by yellow perch. The model suggests that predation by perch could have contributed to the demise of an already declining population of Daphnia in early to mid June, but age-0 yellow perch could not solely have accounted for the decline. Further, prey availability values suggest that perch were close to starvation from the time of hatching until 15 May. Post (1990) calculated observed growth rates for increasing prey availability ( $P$-value) for a larval fish of $10 \mathrm{mg}$, which corresponds to average wet mass on 25 May for Long Lake. Post (1990) suggested that a $P$-value of 0.2 was representative of maintenance ration; any $P$-value $<0.2$ produced negative growth, or starvation, in age- 0 perch. $P$-values were less than 0.2 until 12 May, although at that time perch weighed one-tenth of the value used in Post's model. The increase in $P$-value during late May suggests perch that managed to recruit into larger size classes gained access to more food in the form of Diaptomus and, occasionally, Daphnia. By 6 June, available food, estimated as the total number of Daphnia dying week $^{-1}$, fell too low to bioenergetically support the rate of perch growth (Table 6). This represents a possible bottleneck in growth for the perch population, hypothetically growing at $P$ equal to 1.0 .

Instead, field and model data suggest Bythotrephes was the more probable agent. Daphnia appeared to be an important food resource for Bythotrephes. Peak Bythotrephes density coincided with the beginning of the Daphnia decline; Bythotrephes began to decline after Daphnia declined. Because Daphnia birth rate was low, modest acceleration in the death rate was sufficient to alter Daphnia population dynamics. The rapid increase in the population of Bythotrephes, caused by the large clutches in G1 and G2 females, short maturation time of under a week (the unpublished instar analyses of Hoffman \& Lehman) and iteroparous reproduction by G2 and G3 females (G1 females had disappeared by the time the larger G2 females comprised most of the population), was probably a factor, as well. While iteroparity is common in Daphnia (Threlkeld, 1987), it had not been previously reported in Great Lakes populations of Bythotrephes.

The bioenergetics model demonstrates that Bythotrephes predation is a credible explanation for the decline in Daphnia. Predation by Bythotrephes can account entirely for the death observed in the Daphnia population; moreover, the mean length of Daphnia consumed according to the bioenergetics model was consistent with the observed size distribution of Daphnia.

The perch bioenergetics model has known biases. First, by assuming no mortality in perch, exclusive prey preference for Daphnia and maximum consumption rates after 29 May, we intentionally estimated consumption rates at the maximum value plausible. Although prey preference data for Long Lake perch indicated that Daphnia comprised a small portion of the diet in late May, Mills \& Forney (1981; Table 1) found that it was not unusual for Daphnia to comprise $95 \%$ of young perch (26-31 mm TL) diet. Because yellow perch should have attained such a length in Long Lake during June, we considered that the assumption was biologically reasonable. Secondly, the assumption that perch were growing at a 
temperature equal to that of the upper epilimnion may also have overestimated consumption rate. However, the lake was relatively isothermal from $10 \mathrm{~m}$ to the surface in late June and September, and that zone represented most of the volume of the lake. Adjusting model parameters (e.g. P) to fit empirical data does not correct bias, but it gives a frame of reference to evaluate the potential range of predation on Daphnia by age-0 yellow perch.

Oneida Lake data were used to establish a biologically realistic scenario that projected perch growing at maximum rate. Data for Oneida Lake in 1976 seemed biologically consistent with Long Lake. First, like Long Lake, the pelagic zone of Oneida Lake is dominated by large bodied Daphnia (D. pulex Leydig emend. Richard), its primary planktivore is age-0 yellow perch, and its primary piscivore is walleye (Mills et al., 1989). Secondly, it is improbable that perch were food limited that year; consumption by Oneida Lake yellow perch in 1976 never exceeded $27 \%$ of the production by D. pulex and fish density was low (Mills \& Forney, 1983). Thirdly, Oneida Lake perch sampled at the start of this Oneida Lake time series were approximately $18 \mathrm{~mm}$ in length and $47 \mathrm{mg}$ wet mass; the Long Lake perch sampled on 30 May were 16-21 mm in length and 30.2-62.1 mg wet mass.

Oneida Lake temperature is similar to Long Lake, early August temperature is approximately $24^{\circ} \mathrm{C}$ (Mills et al., 1989), epilimnion temperature for Long Lake during similar periods ranges from 22 to $25^{\circ} \mathrm{C}$. Stratification patterns differ between the two lakes. Oneida Lake is generally homothermal (Mills et al., 1989), whereas Long Lake is generally stratified during the summer months.

Similarities in mass and growth bolster confidence that the bioenergetic model derived for Great Lakes populations of Bythotrephes was appropriate for the Long Lake population. Dry mass of the Long Lake population was between that found in Lakes Erie and Huron, and the magnitude of order difference in mass between the G1 and G3 generations is consistent with Burkhardt's (1994) finding that Lake Michigan Bythotrephes exhibited seasonal variation in dry mass by as much as a factor of five within single instar stages. Further, the mass-specific rate derived from the model declined with increasing instar stage, similar to observations made by Yurista \& Schulz (1995) and consistent with allometric expectation explicit in the growth equations.
The Bythotrephes bioenergetics model also has known biases. The assumption that Bythotrephes exclusively consumes Daphnia may overestimate its contribution to Daphnia mortality. Models based on C and $\mathrm{P}$ budgets have yielded an expectation of strong prey preference for Daphnia (Lehman \& Branstrator, 1995), whereas mesocosm experiments have yielded weak prey preference for Daphnia (Sprules et al., 1990) and suggested it to be a generalist predator (Vanderploeg et al., 1993). However, mesocosm experiments have been inconsistent with massbalance models in determining consumption rate (Yurista \& Schulz, 1995). Allozyme evidence has been offered that Bythotrephes consumes calanoids, cyclopoids and Daphnia, lending support to the generalist hypothesis (Yurista \& Schulz, 1995), but the use of allozymes in diet studies has been criticized and discounted (Giller, 1984; Giller, 1986; Sunderland, 1988). The best hypothesis at present is that Bythotrephes is an opportunistic predator, feeding primarily on Daphnia when it is abundant, and switching to an alternate diet when Daphnia is scarce.

The trophic impact of Bythotrephes appears to ripple throughout the food chain. Effects propagate down the food chain depressing Daphnia and perhaps releasing some phytoplankton from grazing, across its own trophic level by competing with age- 0 perch, and also up the food chain, reducing food resources for walleye and adult yellow perch. If perch in Long Lake were following the typical ontogenetic sequence, and grew by June to a size at which they switch from copepods to Daphnia, food availability would have been severely limited. Possible responses by yellow perch include an early niche shift to feeding on benthic invertebrates, reduced growth and increased mortality. Perch recruitment may be further reduced by food limitation early in life. At the observed size of perch in Long Lake on 12 May (1.1 mg), the calculated $P$-value of 0.2 is below maintenance ration. Perch may be exposed to a period of starvation, greatly increasing the risk of mortality in the population, either from cannibalism by adults (Tarby, 1974) or from reduced burst speed, which increases vulnerability to predation (Webb \& Corolla, 1981; Miller et al., 1988). If a bottleneck to recruitment occurred in Year-One, the few surviving perch might grow exceedingly well because of a low density of conspecifics.

In Long Lake, perch dynamics and biomass are consistent with the idea of a recruitment bottleneck in 
Year-One. Perch are heavier than the average for Michigan lakes in all year classes after Year-One (Michigan Department of Natural Resources, 1997). Walleye, which feed on perch, are growing slower than the state average, suggesting food limitation.

The framework for this study combined zooplankton sampling, age-0 fish sampling, direct feeding analyses and bioenergetics modelling to investigate relationships between zooplankton, planktivorous invertebrates and planktivorous vertebrates. By integrating field data through modelling, we could test a hypothesis with several different lines of evidence. In this case it helped to resolve two competing hypotheses for a natural phenomenon, and has potential to do so in other cases.

\section{Acknowledgements}

James Diana provided advice and assistance with the fish collections, David Jude helped with the yellow perch sampling methodology and identification, Donna and Jeff Lehman helped with field sampling. Barry Lishawa and family provided Secchi disk transparency data from 1992 to 1998 and logistical support for fieldwork. Funding and material support for the project was provided in part by the University of Michigan Undergraduate Research Opportunity Program, Naval Architecture and Marine Engineering, and the Center for Great Lakes and Aquatic Sciences.

\section{References}

Auer N.A. (Ed.) (1982) Identification of Larval Fishes of the Great Lakes Basin with Emphasis on the Lake Michigan Drainage. Great Lakes Fishery Commission, Ann Arbor, MI, Special Publication 82-3.

Bilkovic D.M. \& Lehman J.T. (1997) Lipid concentration and size variation in Bythotrephes (Cladocera: Cercopagidae) from Lakes Erie, Huron and Michigan. Journal of Great Lakes Research, 23, 149-159.

Brett M.T. \& Goldman C.R. (1997) Consumer versus resource control in freshwater pelagic food webs. Science, 275, 384-386.

Burkhardt S. (1991) Phosphorus turnover, prey consumption, and size variation of the predatory cladoceran Bythotrephes cederstroemi in Lake Michigan. MS Thesis, University of Michigan, Ann Arbor, MI.

Burkhardt S. (1994) Seasonal size variation in the predatory cladoceran Bythotrephes cederstroemi in Lake Michigan. Freshwater Biology, 31, 97-108.
Burkhardt S. \& Lehman J.T. (1994) Prey consumption and predatory effects of an invertebrate predator (Bythotrephes: Cladocera, Cercopagidae) based on phosphorus budgets. Limnology and Oceanography, 39, 1007-1019.

Carpenter S.R., Kitchell J.F. \& Hodgson J.R. (1985) Cascading trophic interactions and lake productivity. Bioscience, 35, 634-639.

Carpenter S.R., Hodgson J.R., Cochran P.A., Elser J.J., Elser M.M., Lodge D.M., Kretchmer D., He X. \& von Ende C.N. (1987) Regulation of lake primary productivity by food web structure. Ecology, 68, 1863-1876.

Carpenter S.R. \& Kitchell J.F. (1988) Consumer control of lake productivity. Bioscience, 38, 764-769.

Confer J.L. \& Lake G.J. (1987) Influence of prey type on growth of young yellow perch (Perca flavescens). Canadian Journal of Fisheries and Aquatic Sciences, 44, 2028-2033.

De Bernardi R. \& Guissani G. (1975) Population dynamics of three cladocerans of Lago Maggiore related to predation pressure by a planktophagous fish. Verhandlungen der Internationale Vereinigung für Theoretische und Angewandte Limnologie, 19, 2906-2912.

Edmondson W.T. \& Litt A.H. (1982) Daphnia in Lake Washington. Limnology and Oceanography, 27, 272-293.

Fee E.J. (1990) Computer programmes for calculating in situ phytoplankton photosynthesis. Canadian Technical Report of Fisheries and Aquatic Science.

Giller P.S. (1984) Predator gut state and prey detectability using electrophoretic analysis of gut contents. Ecological Entomology, 9, 157-162.

Giller P.S. (1986) The natural diet of Notonectidae: field trials using electrophoresis. Ecological Entomology, 11, 163-172.

Hansen M.J. \& Wahl D.H. (1981) Selection of small Daphnia pulex by yellow perch fry in Oneida Lake, New York. Transactions of the American Fisheries Society, 110, 64-71.

Hrbácek J. (1962) Species composition and the amount of zooplankton in relation to the fish stock. Rozpravy Ceské Akademie Ved, 72, 1-116.

Hunter J.R. (1981) Feeding ecology and predation of marine fish larvae. In: Marine Fish Larvae. (Ed. R. Lasker), pp. 33-79. University of Washington Press, Seattle, WA.

Ivlev V.S. (1961) Experimental Ecology of the Feeding of Fishes. Yale University Press, New Haven, CT.

Kitchell J.F., Steward D.J. \& Weininger D. (1977) Applications of a bionergetics model to yellow perch (Perca flavescens) and walleye (Stizostedion vitreum vitreum). Journal of the Fisheries Research Board of Canada, 34, 1922-35.

Kitchell J.F., Koonce J.F., O'Neill R.V., Shugart H.H. Jr, Magnuson J.J. \& Booth R.S. (1974) Model of Fish 
Biomass Dynamics. Transactions of the American Fisheries Society, 103, 786-798.

Lampert W. (1978) Climatic conditions and planktonic interactions as factors controlling the regular succession of spring algal bloom and extremely clear water in Lake Constance. Verhandlungen der Internationale Vereinigung für Theoretische und Angewandte Limnologie, 20, 969-974.

Lampert W., Fleckner W., Rai H. \& Taylor B.E. (1986) Phytoplankton control by grazing zooplankton: a study of the spring clear-water phase. Limnology and Oceanography, 31, 478-490.

Lasker R. (1975) Field criteria for survival of anchovy larvae: the relation between inshore chlorophyll maximum layers and successful first feeding. Fishery Bulletin, 73, 453-462.

Lehman J.T. (1988) Algal biomass unaltered by food-web changes in Lake Michigan. Nature, 332, 537-538.

Lehman J.T. (1991) Causes and consequences of cladoceran dynamics in Lake Michigan: implications of species invasion by Bythotrephes. Journal of Great Lakes Research, 17, 437-445.

Lehman J.T., Bilkovic D.M. \& Sullivan C. (1997) Predicting development, metabolism and secondary production of the invertebrate predator Bythotrephes. Freshwater Biology, 38, 101-110.

Lehman J.T. \& Branstrator D.K. (1995) A model for growth, development, and diet selection by the invertebrate predator Bythotrephes cederstroemi. Journal of Great Lakes Research, 21, 610-619.

Lehman J.T. \& Cáceres C.E. (1993) Food-web responses to species invasion by a predatory invertebrate: Bythotrephes in Lake Michigan. Limnology and Oceanography, 38, 879-891.

Makarewicz J.C. \& Likens G.E. (1979) Structure and function of the zooplankton community of Mirror Lake, New Hampshire. Ecological Monographs, 49, 109-127.

Michigan Department of Natural Resources (1997) Fish Collection System: Long Lake, Grand Traverse County. Lake and stream files, Fisheries Division Center for Research, Ann Arbor, MI.

Miller T.J., Crowder L.B., Rice J.A. \& Marshall E.A. (1988) Larval size and recruitment mechanisms in fishes: toward a conceptual framework. Canadian Journal of Fisheries and Aquatic Sciences, 45, 657-1670.

Mills E.L. \& Forney J.L. (1981) Energetics, food consumption and growth of young yellow perch in Oneida Lake, New York. Transactions of the American Fisheries Society, 110, 479-88.

Mills E.L. \& Forney J.L. (1983) Impact on Daphnia pulex of predation by young yellow perch in Oneida Lake, New York. Transactions of the American Fisheries Society, 112, 154-161.
Mills E.L., Confer J.L. \& Ready R.C. (1984) Prey selectivity by young yellow perch: the influence of capture success, visual acuity, and prey choice. Transactions of the American Fisheries Society, 113, 579-587.

Mills E.L., Forney J.L. \& Wagner K.J. (1987) Fish predation and its cascading effect on the Oneida Lake food chain In: Predation: Direct and Indirect Impacts on Aquatic Communities. (Eds W.C. Kerfoot \& A. Sih), p. 118-131. University Press of New England, Hanover, NH.

Mills E.L., Sherman R. \& Robson D.S. (1989) Effect of zooplankton abundance and body size on growth of age-0 yellow perch (Perca flavescens) in Oneida Lake, New York, 1975-86. Canadian Journal of Fisheries and Aquatic Sciences, 46, 880-886.

Mordukhai-Boltovskaya E.D. (1958) Preliminary notes on the feeding of the carnivorous cladocerans Leptodora kindtii and Bythotrephes. Doklady Akademii Nauk SSSR, 122, 828-830.

Paloheimo J.E. (1974) Calculation of instantaneous birth rate. Limnology and Oceanography, 19, 692-694.

Pastorok R.A. (1978) Predation by Chaoborus larvae and its impact on the zooplankton community. PhD Thesis, University of Washington, Seattle, WA.

Post J.R. (1990) Metabolic allometry of larval and juvenile yellow perch (Perca flavescens): in situ estimates and bioenergetic models. Canadian Journal of Fisheries and Aquatic Sciences, 47, 554-560.

Post J.R. \& McQueen D.J. (1988) Ontogenetic changes in the distribution of larval and juvenile yellow perch (Perca flavescens): a response to prey or predators? Canadian Journal of Fisheries and Aquatic Sciences, 45, 1820-1826.

Rice J.A. \& Cochran P.A. (1984) Independent evaluation of a bioenergetics model for largemouth bass. Ecology, 65, 732-739.

Salonen K., Sarvala J., Hakala I. \& Viljanen M.L. (1976) The relation of energy and organic carbon in aquatic invertebrates. Limnology and Oceanography, 21, 724-730.

Sprules W.G., Riessen H.P. \& Jin E.H. (1990) Dynamics of the Bythotrephes invasion of the St. Lawrence Great Lakes. Journal of Great Lakes Research, 16, 346-351.

Sullivan C.A. \& Lehman J.T. (1997) Character variation and evidence for spine length selection in the invertebrate predator Bythotrephes (Crustacea: Cladocera) from Lakes Michigan, Huron, and Erie. Archiv für Hydrobiologie, 142, 35-52.

Sunderland K.D. (1988) Quantitative methods for detecting invertebrate predation occurring in the field. Annals of Applied Biology, 112, 201-224.

Tarby M.J. (1974) Characteristics of yellow perch cannibalism in Oneida Lake and its relation to first year

(C) 2001 Blackwell Science Ltd, Freshwater Biology, 46, 759-775 
survival. Transactions of the American Fisheries Society, 103, 462-471.

Threlkeld S.T. (1987) Daphnia life history strategies and resource allocation patterns. In: Daphnia (Eds R.H. Peters \& R. De Barnardi). Memorie Istituto dell'Italiano di Idrobiologia, 45, 353-366

Vanderploeg H.A., Liebig J.R. \& Omair M. (1993) Bythotrephes predation on Great Lakes' zooplankton measured by an in situ method: implications for zooplankton community structure. Archiv für Hydrobiologie, 127, 1-8.

Wahl C.M., Mills E.L., McFarland W.N. \& DeGisi J.S. (1993) Ontogenetic changes in prey selection and visual acuity of the yellow perch, Perca flavescens. Canadian Journal of Fisheries and Aquatic Sciences, 50, 743-749.

Wanzenböck J., Whiteside M.C. \& Mehner T. (1997) Defining a desirable sampling strategy for studies of age-0 fish - zooplankton interactions - A preliminary approach. Archiv für Hydrobiologie, 49, 137-138.
Webb P.W. \& Corolla R.T. (1981) Burst swimming performance of northern anchovy, Engraulis mordax, larvae. Fisheries Bulletin, 79, 143-150.

Yan N.D. \& Pawson T.W. (1997) Changes in the crustacean zooplankton community of Harp Lake, Canada, following invasion by Bythotrephes cederstroemi. Freshwater Biology, 37, 409-425.

Yurista P.M. (1992) Embryonic and postembryonic development in Bythotrephes cederstroemi. Canadian Journal of Fisheries and Aquatic Sciences, 49, 1118-1125.

Yurista P.M. \& Schulz K.L. (1995) Bioenergetic analysis of prey consumption by Bythotrephes cederstroemi in Lake Michigan. Canadian Journal of Fisheries and Aquatic Sciences, 52, 141-150.

Zaret T.M. (1980) Predation and Freshwater Communities. Yale University Press, New Haven, CT.

(Manuscript accepted 29 September 2000) 